\title{
Prenylated $p$-Hydroxyacetophenone Derivatives from the Giant Senecio johnstonii
}

\author{
S. DUPRÉ, F. BOHLMANN and E. KNOX* \\ Institute for Organic Chemistry, Technical University of Berlin, D-1000 Berlin 12, F.R.G.; \\ *The University of Michigan, Ann Arbor, MI 48109-1048, U.S.A.
}

Key Word Index-Senecio johnstonï; Compositae; prenylated p-hydroxyacetophenone derivatives; umbelliferone derivative; alkylated resorcinol.

Abstract-The extract of the aerial parts of $S$. johnstonii afforded five known prenylated $p$-hydroxyacetophenone derivatives, scopoletin and 5-pentadecyl resorcinol together with the tridecyl derivative. The chemotaxonomic situation is discussed briefly.

\section{Introduction}

The group of giant Senecios contains three species, all restricted to East Africa [1]. As the relationship of this group to other groups of Senecio is of interest we have studied the chemistry of one species, $S$. johnstonii Oliv. ssp. adnivalis (Stapf) C. Jeffrey var. erici-rosenii (R. E. \& T. L. E. Fries) C. Jeffrey, grown from seeds, collected from Mt Karisimbi in Rwanda. The main constituent is the methyl ether of 2senecioyl-p-hydroxyacetophenone (4) [2]. Furthermore, the $p$-hydroxyacetophenone derivatives 1 [3], 2 [4], 3 [5] and 5 [6] as well as scopoletin (6) and the 5-alkyl resorcinols $7[7,8]$ and 8 [8] were present. The structures were elucidated by their high field ${ }^{1} H$ NMR spectra which were compared with those of authentic samples.

The results show that the typical furoeremophilanes, present in most groups of Senecio and related genera like Euryops, Ligularia and Othonna, are absent. Prenylated phydroxyacetophenones have been reported from some Senecio species, however, so far mainly euparinlike derivatives [9]. The diketones 3 and 4 have never been isolated from Senecio species. Prenyl- $p$-hydroxyacetophenone was reported from only three species [10-12].

Scopoletin (6) is also rare in Senecio, it has been reported from only one species [13]. The

(Received 9 January 1990)<smiles>[X]C1CC(C)(C)Oc2ccc(C(C)=O)cc21</smiles>

$1 \mathrm{X}=\mathrm{H}_{2}$

$2 \mathrm{X}=0$<smiles>C=C(C)C1Cc2cc(C(C)=O)c(O)cc2O1</smiles>

5<smiles>[R]Oc1ccc(C(C)=O)cc1C(=O)C=C(C)C</smiles>

$3 \mathbf{R}=\mathrm{H}$

$4 \mathrm{R}=\mathrm{Me}$<smiles>COc1cc2ccc(=O)oc2cc1O</smiles>

6

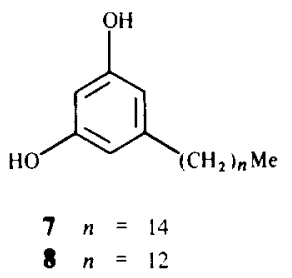

resorcinol derivatives 7 and 8 have so far been isolated in the Compositae only from a Baccharis species. Thus the chemistry of $S$. johnstonii is relatively unusual. The analysis of this species may indicate that it is derived from a very old lineage within Senecio as the prenylated $p$ hydroxyacetophenones are more accumulated in other tribes especially in the Eupatorieae. 


\section{Experimental}

The air-dried aerial parts $(200 \mathrm{~g})$ were extracted with $\mathrm{MEOH}-$ $\mathrm{Et}_{2} \mathrm{O}$-petrol, 1:1:1, at room temperature. The extract obtained was separated by CC, TLC and HPLC as reported previously [14]. Finally $10 \mathrm{mg} \mathrm{1,100} \mathrm{mg} \mathrm{2,100} \mathrm{mg} \mathrm{3,1.5} \mathrm{g} \mathrm{4,} 200 \mathrm{mg} \mathrm{5,} 50$ $\mathrm{mg} \mathrm{6}, 350 \mathrm{mg} 7$ and $170 \mathrm{mg} 8$ were isolated. The compounds were identified by comparing the $400 \mathrm{MHz}{ }^{1} \mathrm{H}$ NMR spectra with those of authentic material.

Acknowledgements-E. K. thanks the Government of Rwanda and officials at O.R.T.P.N., the Parc des Volcans and Karisoke Research Center for permission and assistance in concluding the field work and the U.S. National Science Foundation for the grants BSE- 8800487 and 8901123 .

\section{References}

1. Jeffrey, C. (1986) Kew Bull. 41, 873.

2. Bohlmann, F. and Rao, N. (1973) Chem. Ber. 106, 3035.

3. Bohlmann, F., Zdero, C. and Lonitz, M. (1977) Phytochemistry 16, 575 .
4. Ekundayo, O., Laakso, I. and Hiltunen, R. (1988) Planta Med. 54, 55.

5. Bohlmann, F., Mahanta, P. K., Suwita, A., Suwita, Ant., Natu, A. A., Zdero, C., Dorner, W., Ehlers, D. and Grenz, M. (1977) Phytochemistry 16, 1973.

6. Bohlmann, F. and Grenz, M. (1970) Chem. Ber. 103, 90.

7. Ridley, D. D., Ritchie, E. and Taylor, W. C. (1968) Aust. J. Chem. 21, 2979.

8. Bohlmann, F., Kramp, W., Grenz, M., Robinson, H. and King, R. M. (1981) Phytochemistry 20, 1907.

9. Bohimann, F., Zdero, C., Berger, D., Suwita, A., Mahanta, P. K. and Jeffrey, C. (1979) Phytochemistry 18, 79.

10. Bohlmann, F. and Zdero, C. (1980) Phytochemistry 19, 2681.

11. Loyola, L. A., Pedresos, S. and Morales, G. (1985) Phytochemistry 14, 1600.

12. Ehlers, D., Le Van, N., Abraham, W. R. and Natu, A. A. (1977) Phytochemistry 16, 965.

13. Bohlmann, F., Kramp, W., Robinson, $H_{\text {. }}$ and King, R. $M$. (1981) Phytochemistry 20, 1739.

14. Bohlmann, F., Zdero, C., King, R. M. and Robinson, $H$. (1984) Phytochemistry 23, 1979. 